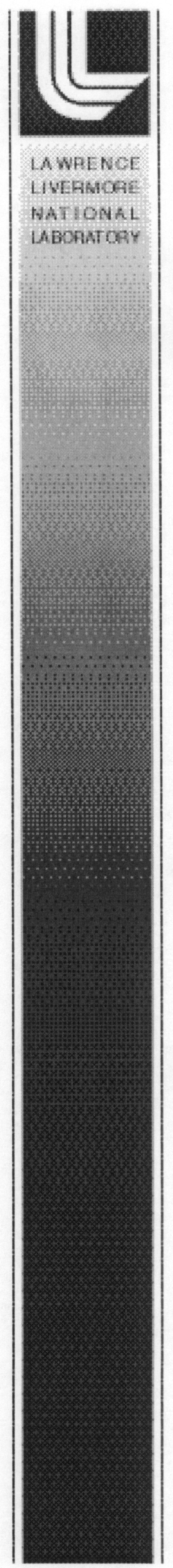

\title{
UCRL-ID-149146
}

\section{Laser Peeing of Alloy 22 Welds}

D. W. Stevens, L. A. Hackel, A. C. Lingenfelter

October 3, 2002 
This document was prepared as an account of work sponsored by an agency of the United States Government. Neither the United States Government nor the University of California nor any of their employees, makes any warranty, express or implied, or assumes any legal liability or responsibility for the accuracy, completeness, or usefulness of any information, apparatus, product, or process disclosed, or represents that its use would not infringe privately owned rights. Reference herein to any specific commercial product, process, or service by trade name, trademark, manufacturer, or otherwise, does not necessarily constitute or imply its endorsement, recommendation, or favoring by the United States Government or the University of California. The views and opinions of authors expressed herein do not necessarily state or reflect those of the United States Government or the University of California, and shall not be used for advertising or product endorsement purposes.

This work was performed under the auspices of the U.S. Department of Energy by University of California, Lawrence Livermore National Laboratory under Contract W-7405-Eng-48. 


\section{Laser Peening of Alloy 22 Welds}

\section{Donald W. Stevens \\ Lloyd A. Hackel \\ Allen C. Lingenfelter}

\section{Laser Peening Concept}

Laser Input at $\sim 120-180 \mathrm{~J} / \mathrm{cm}^{2}$

with -20 ns pulse duration

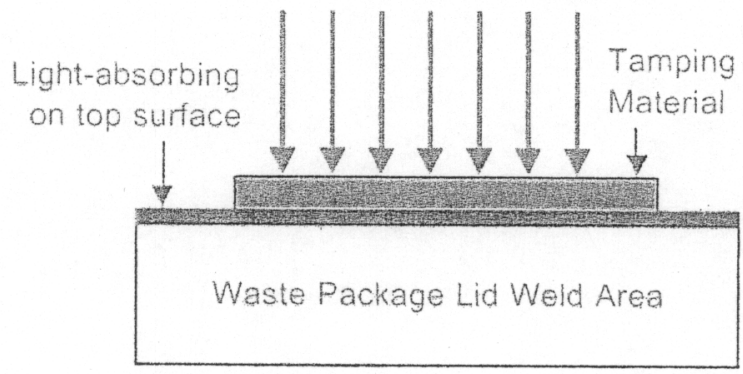

In a single pass, this process is capable of producing compressive layers in Alloy 22 welds at depths of $1.5 \mathrm{~mm}$. In multiple-pass application, compressive layers can be produced at depths of $3 \mathrm{~mm}$.

July 2002

\section{Lawrence Livermore} National Laboratory Livermore, CA 94550
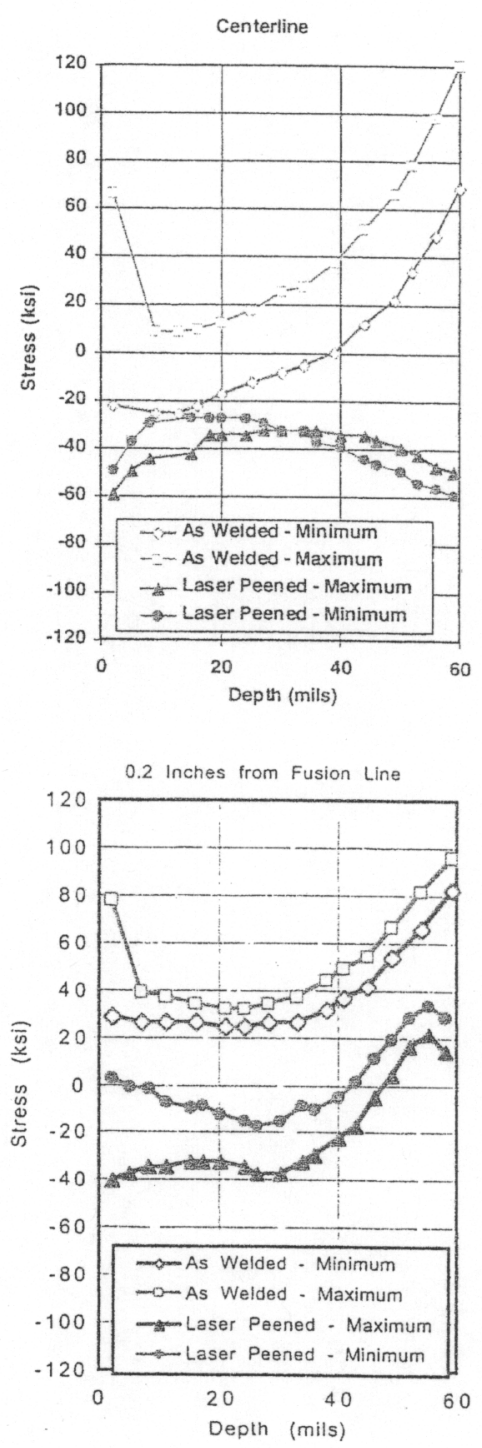


\title{
Laser Peening of Alloy 22 Welds
}

\author{
Donald W. Stevens, Lloyd A. Hackel, and Allen C. Lingenfelter \\ Lawrence Livermore National Laboratory, Livermore, CA
}

\section{EXECUTIVE SUMMARY}

Stress corrosion cracking (SCC) of near-surface Alloy 22 metal can be propagated by yield-point levels ( $45 \mathrm{ksi}$ ) of residual weld tensile stresses. This is a serious concern for welds in the Alloy 22 canister employed in the Yucca Mountain Project (YMP) Waste Package, particularly in closure welds that cannot be stress relieved by conventional heat treating. This work shows that compressive shock waves, driven into a weldment by laser peening, replaces its detrimental tensile stresses of 30-80 ksi with compressive stresses of $2-25 \mathrm{ksi}$ or better that retard SCC. This benefit occurs in the top $1.5 \mathrm{~mm}$ (or more) of the material without appreciable heating.

It was aiso found that quenching after solution annealing and shot peening during production of Alloy 22 plate imparts compressive stresses of 35-105 ksi near the (surface, a very large buffer against SCC. This means that if seam-welded hollow canisters likewise gain compressive stresses upon post-weld annealing and quenching, and if closure welds are laser peened, all surfaces of the canister would be under compression, thereby precluding SCC of the Alloy 22 canister.

Laser peening may plastically deform as much as the top $10 \%$ of the metal (about $2 \mathrm{~mm}$ out of the $25-\mathrm{mm}$ plate thickness), thereby changing the rate of general corrosion of waste package outer barrier. Long-term corrosion tests of laser peened Alloy 22 welds should be conducted.

Present results show that laser peening, currently under development at LLNL using high-energy lasers, induces compressive residual stress on the near surface of the weld. This laser peening process is showing significant retardation of SCC and should be further characterized and assessed to preclude SCC in Alloy 22 canisters. 


\section{INTRODUCTION AND SUMMARY}

The Yucca Mountain Program (YMP) Engineered Barrier's Waste Package (WP) will contain a canister fabricated from mill-annealed plate of Alloy 22, a $\mathrm{Ni} / \mathrm{Cr} / \mathrm{Mo} / \mathrm{W}$ alloy. Calculations based on recent experimental data indicate a propensity for stress corrosion cracking (SCC) to occur in Alloy 22 for the case of large internal defects and high tensile (but not compressive) stresses.' It was found in this work that large residual tensile stresses of 30-80 ksi in the near-surface, SCC-susceptible material developed upon welding. These are on the order of the nominal 45-ksi-yield strength of the material, thus meeting the high stress criterion. Stresses from other sources inducted during fabrication, such as bending of plates into cylinders and shrink fitting of two concentric cylinders, are negligibly low. ${ }^{2}$ The fabrication sequence of the WP could conceptually include a solution anneal to stress relieve all welds except the closure weld.

The purpose of this work was to demonstrate whether laser peening would reduce the closure weld residual tensile stresses sufficiently to preclude SCC. Laser peening was selected because of its ability to impart deep (about $1.5 \mathrm{~mm}$ ) compressive stresses in ferrous and nickel-based alloys and its advantages over shot peening such as less work hardening, as well as its ability to make multiple passes to obtain deeper compressive stresses. ${ }^{3}$ During the laser peening process, the temperature of the metal surface will increase by about $140^{\circ} \mathrm{F}$ for a second or so. And most importantly, the laser system can be readily engineered to be remotely controlled and thus compatible in the hot cell environment in which it must operate.

Laser peening was done with a high-energy, pulsed Nd-glass laser at LLNL. Figure 1 is an illustration of the laser peening process for stress mitigation. The laser system is an advanced design that operates at 25 times the pulse rate of competing technologies suitable of laser peening. A series of laser peening experiments were done to establish the operating window for producing deep compressive residual stress on Alloy 22 plates and welds. Residual stresses were measured with the mechanical ring-core method on four types of samples: as-received, welded, peened-as-received, and welded plus peened.

It was found for welds, that high yield-level ${ }^{4}$ residual tensile stresses of $(30-80 \mathrm{ksi})$ in the near-surface material reverted upon laser peening to compressive stresses of 2-25 ksi on the weld surface, thus eliminating the tensile stress that would enable SCC. It was also found that solution anneal quenching and grit peening during the manufacture of the Alloy 22 plate employed in this work placed it under a deep compression of 35-105 ksi,

\footnotetext{
${ }^{1}$ Huang, Jia-Song (1998). Stress Corrosion Cracking in Canistered Wasted Package Containers: Welds and Base Metals. (UCRL-ID130063) Livermore, CA: Lawrence Livermore National Laboratory. [MOL.19980126.0059]

${ }^{2}$ Stevens, D.W. (1998). "Phase Stability and Residual Stress Issues for YMP Canisters". In Workshop on Phase Stability in Nickel Alloys for Radioactive Waste Containers. Toronto, Ontario: Nickel Development Institute. [MOL.19980618.0080]

${ }^{3}$ C. Brent Dane, Lloyd A. Hackel, James Daly, and James Harrison, High Power Laser for Peening of Metals Enabling Production Technology, UCRL-JC-131104 rev 1, 1998, Lawrence Livermore National Laboratory, Livermore, CA.

${ }^{4}$ Nominal yield strength for Alloy 22 is $45 \mathrm{ksi}$ at room temperature. The heat used in this work had a certified yield of $47.4 \mathrm{ksi}$.
} 
which is quite advantageous for YMP. If a like gain in compression occurs upon annealing and quenching seam welds of the hollow canisters to relieve their residual tensile stresses and if closure welds are laser peened, then all surfaces of the Alloy 22 canister will be under compression and free of SCC.

\section{Laser Peening Concept}

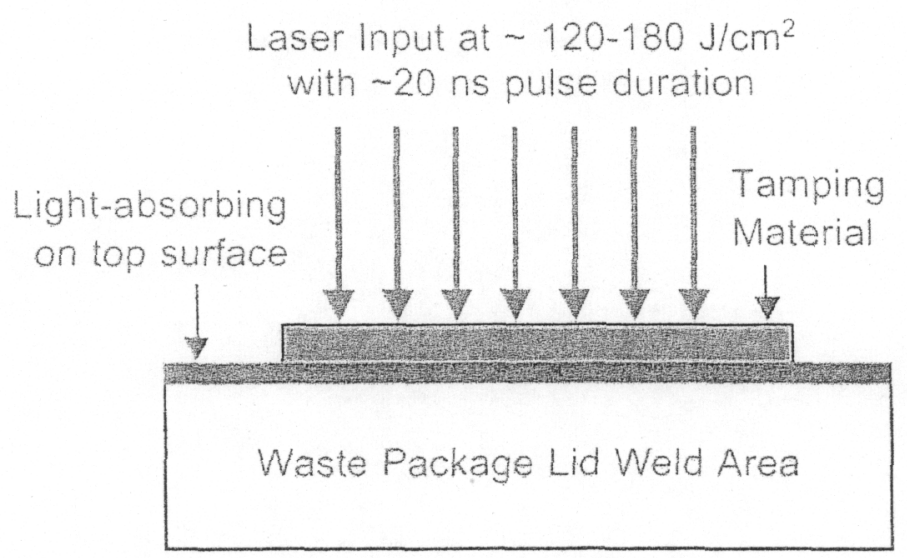

Figure 1. Illustration of laser peening process for stress mitigation.

In a single pass, this process is capable of producing compressive stress in Alloy 22 welds at depths greater than 60 mils $(1.5 \mathrm{~mm})$. In multiple-pass applications, compressive layers can be produced at depths of $3 \mathrm{~mm}$. Figures 2 and 3 show the distributions of stress produced in Alloy 22 during single-pass laser peening.
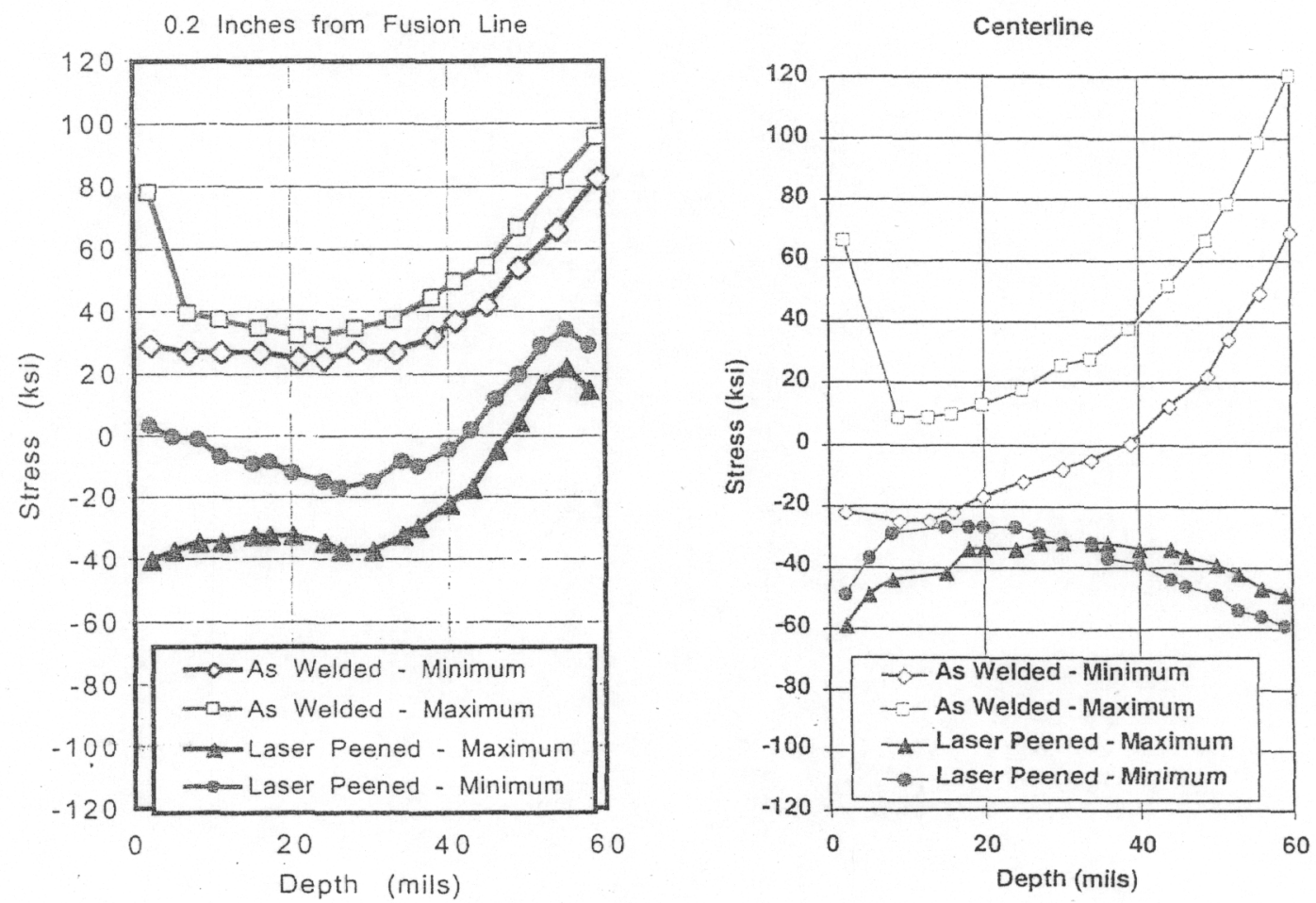

Figure 2 (left). Residual weld stress in Alloy 22 at position 0.2 inches from the fusion line. Figure 3 (right). Residual weld stress in Alloy 22 at the center of the fusion line. 
The surfaces of laser-peened areas in the As-Received Plate were plastically deformed into 6-8 $\mu \mathrm{m}$ depressions. AFM revealed that dislocation slip bands and, perhaps, deformation twins striated the surfaces of the depressions. The lower residual strain energy from twinning makes it very preferable over slip bands. The peening increased Rockwell B hardness by $2 \%$ and DPH micro-hardness by $8 \%$, whereas the residual compressive stresses increased by $140 \%$. One would have expected a stronger relative increase between the hardness/micro-hardness and residual stress given that both strain-sensitive properties were subjected to the same shock-wave cold working.

The compressive shock wave from laser peening imparts cold working in the form of depressions 6-8 $\mu \mathrm{m}$ deep. This plastically deformed metal might also change the rate of general corrosion which should be measured in future experiments. It is evident from the stress relief gained here that laser peening should be further characterized and assessed as a step in fabricating the YMP Waste Package. 


\section{LASER PEENING TESTS AND STRESS MEASUREMENTS}

\section{Preparation of As-Received Material}

The material employed in this work was a 1"-thick plate of mill-annealed Alloy 22, 13" $x$ 18", purchased from Metal Samples Company, Munford, AL, on 1/4/99, PO\#B503512. Haynes produced it as their alloy C-22 ${ }^{\mathrm{TM}}$, identified by them as ASTM-B-575-94, NO6022, Item P490-41276, with a yield stress of 47,400 psi. A Statement of Conformity and Certified Material Test Report was mailed to LLNL on 2/18/99. "C-22" and "HT $\mathrm{P} 490$ " were stamped on the plate in two locations.

The plate was slowly cut into samples with water flow to minimize heating. One sample was a $1^{\prime \prime} \times l^{\prime \prime} \times 18^{\prime \prime}$ strip to represent the as-received material. It was further cut into a 1 " $\times$ $1 " \times 3$ " sample named As-Received Plate, shown in Fig. 4, as well as some X-ray samples not employed directly in this work..$^{5}$ All surfaces of these samples were lapped and electropolished to minimize surface irregularities and to remove any stressed material that might have resulted from handling damage. The lapping was done in metallographic fashion down to a 4- $\mu \mathrm{m}$ finish or better. To the unaided eye, it looked bright and shiny with sparse, barely discernable scratching. This was followed by electropolishing a minimum of 2 mils from each surface in 75 vol\% phosphoric acid and $25 \mathrm{vol} \%$ sulfuric acid at $175^{\circ} \mathrm{F}$. The remaining $I^{\prime \prime} \times 13^{\prime \prime} \times 17^{\prime \prime}$ piece served as the start of the Weld Plate sample.

\section{Residual Stress Measurement}

Residual stresses in the As-Received Plate and Weld Plate samples were measured before and after laser peening. $X$-ray diffraction and the ring-core method of mechanical relaxation are common methods for this. $X$-ray diffraction is generally preferred because of its greater accuracy, but the ring-core method is employed when accessibility by $x$-ray diffraction is extremely difficult or costly, or when diffraction effects from the microstructure of the metal, particularly large grain size, obscure $x$-ray diffraction patterns. In our case, $x$-ray diffraction was employed once but was found to suffer signal degradation by the grain size effect. Thereafter, the ring core method was used. It involves epoxying three thin-film strain gages in a rosette pattern $45^{\circ}$ from each other $\left(0^{\circ}\right.$, $45^{\circ}$, and $90^{\circ}$ ), then machining out (coring) an annular ring of material (a ring), nominally 0.25 in. in diameter, just outside the rosette. A digital photograph of a ring core in $A s^{-}$ Received Plate is shown in Fig. 5. It was cored by EDM (electrode discharge machining).

${ }^{5}$ These were intended to serve an X-ray diffraction study of residual stresses at LLNL. Some were 20 $\%$ cold rolled in about $2 \%$ increments, using alternating 90 degree cross rolling to reduce grain elongation. 


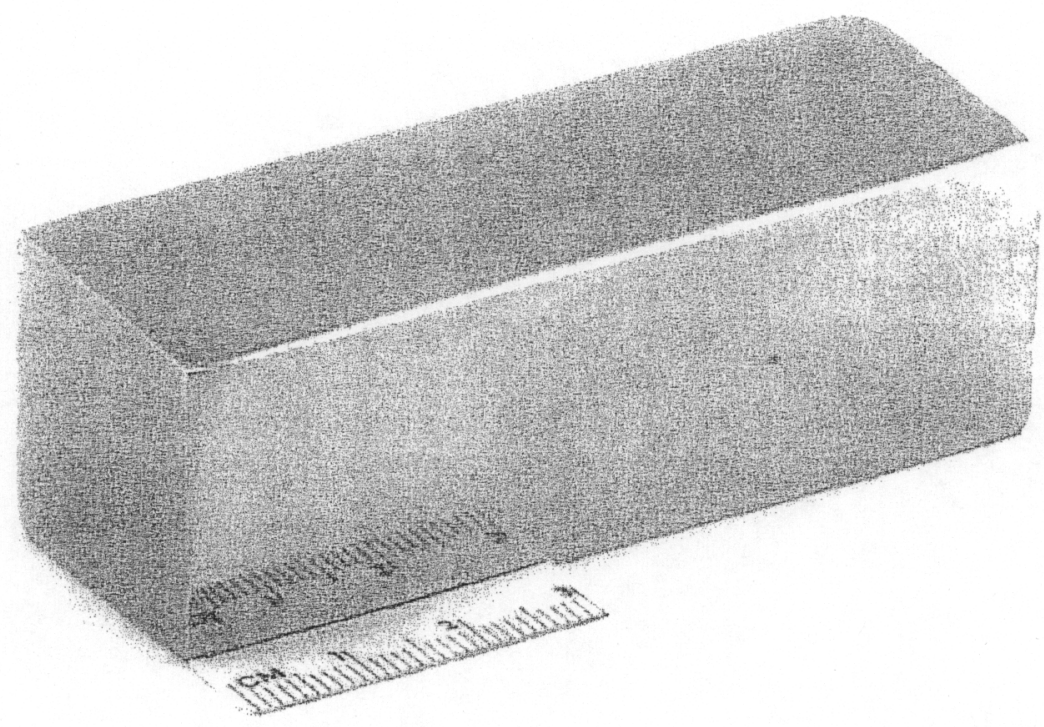

Figure 4. As-Received Plate of Alloy 22. This sample was employed to establish the laser operation window by measuring its residual stresses before and after laser peening with various laser operating parameters. All surfaces were lapped and electropolished beforehand to minimize surface stress artifacts.

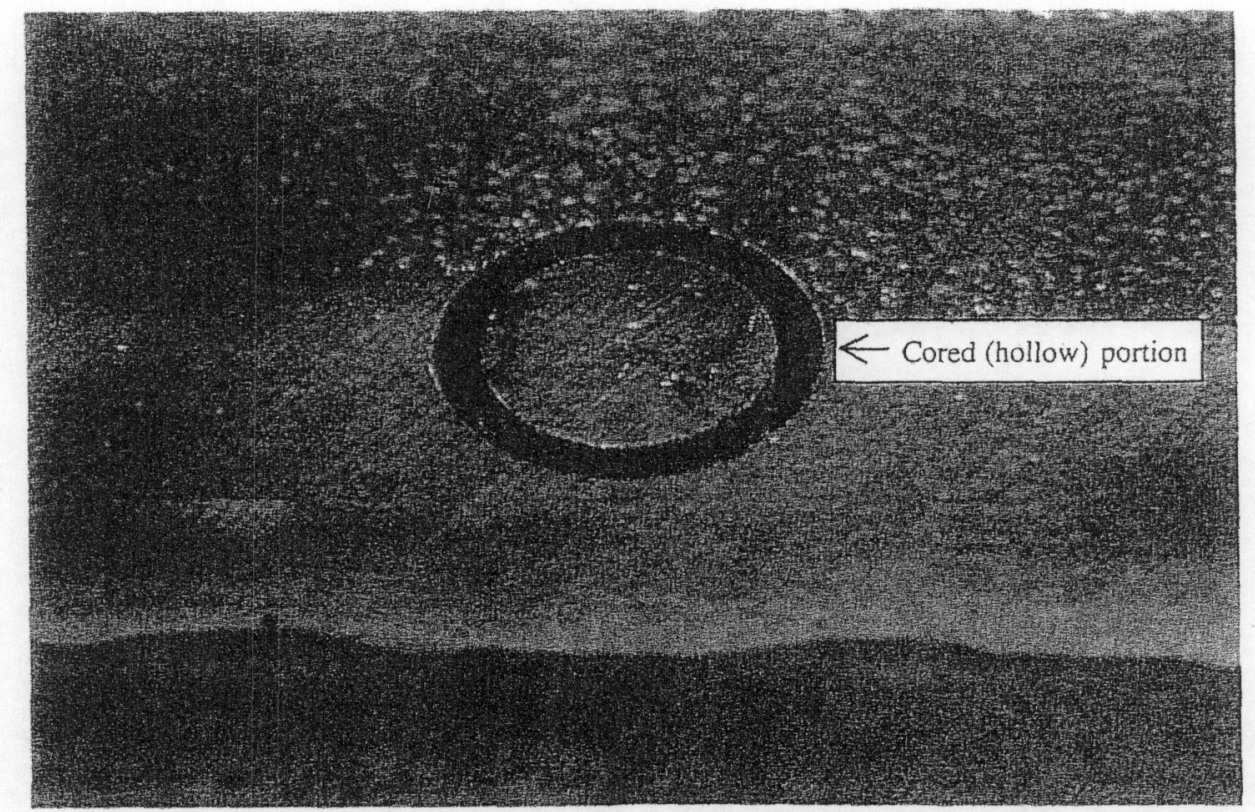

Figure 5. A ring core in As-Received Plate employed to measure residual stress.

Material surrounding the hollow ring will relax into or away from the open space of the core according to the type (tension or compression) and magnitude of the residual strain. The residual strain relieved in the process is recorded and used to calculate the residual stress, using the elastic (Young's) and shear modulus to relate the two. Strains are measured as a function of depth by successively machining the annular groove from an initial depth of 1.5 mils (referred as the "near-surface" material) to depths of nearly 60 mils $(1.5 \mathrm{~mm})$ in increments of about 5 mils. 


\section{Preparation of the Weld Plate and Surface for Peening}

Three, heavy, steel bar "strong-backs" were welded across the back of the l" $\times 13^{\prime \prime} \times 17^{\prime \prime}$ starting plate to help retain the residual stresses that develop upon cool-down after welding. These are depicted in Fig. 6 and are seen in the photographs of Figs. 7 and 8. A weld preparation was then machined along the center of the plate. It featured a groove angle with a $0.5^{\prime \prime}$ opening, a groove radius of $0.25^{\prime \prime}$, and a depth of bevel of $0.8^{\prime \prime}$ into the 1 " plate. The weld process was prototypical for YMP Waste Containers and featured multiple-pass hot wire GTAW with Alloy 22 filler metal. The fusion zone measured about $0.6^{\prime \prime}$ wide and can be seen in Figs. 9 and 10.

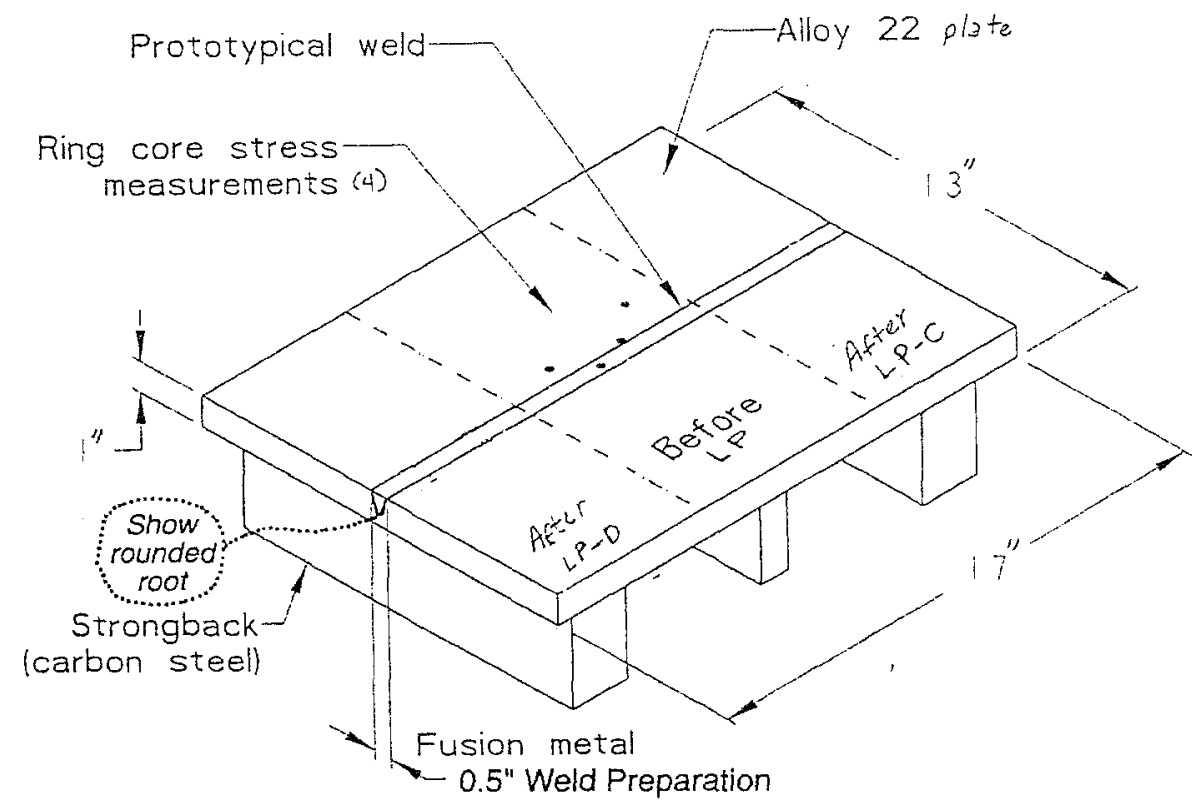

Figure 6. Schematic of the Weld Plate and the laser peening experiment. Areas shown are Before LP (laser peening) with its loci of ring cores for measuring residual stresses and After $L P-C$ and $D$, where $C$ and $D$ are sets of laser parameters.

The Nd-glass laser operation employed a black plastic tape as a laser energy-absorbing layer and a film of water on top of it (maintained by a stream of water) as the tamping layer. Alternate materials to the plastic tape and water tamper can be used as needed. The plastic layer can be seen in Figs. 8-10 and the water jet in Fig. 11. About $10 \%$ of the thickness of the tape is volatilized by the high-intensity laser beam and transformed into a high-pressure plasma of about $10^{6}$ psi. This pressure, restained during the 20 -ns pulse duration by the inertial mass of the water film (tamping film), is then driven into the metal as an intense, compressive shock wave. The laser fluence (joules per $\mathrm{cm}^{2}$ ) and peak power density $\left(\mathrm{GW} / \mathrm{cm}^{2}\right)$ are adjusted so that the peak pressure of the shock exceeds the yield strength of the material and thus plastically strains the metal, leaving a residual compressive stress in the $\mathrm{mm}$ to several-mm depth of the surface. 


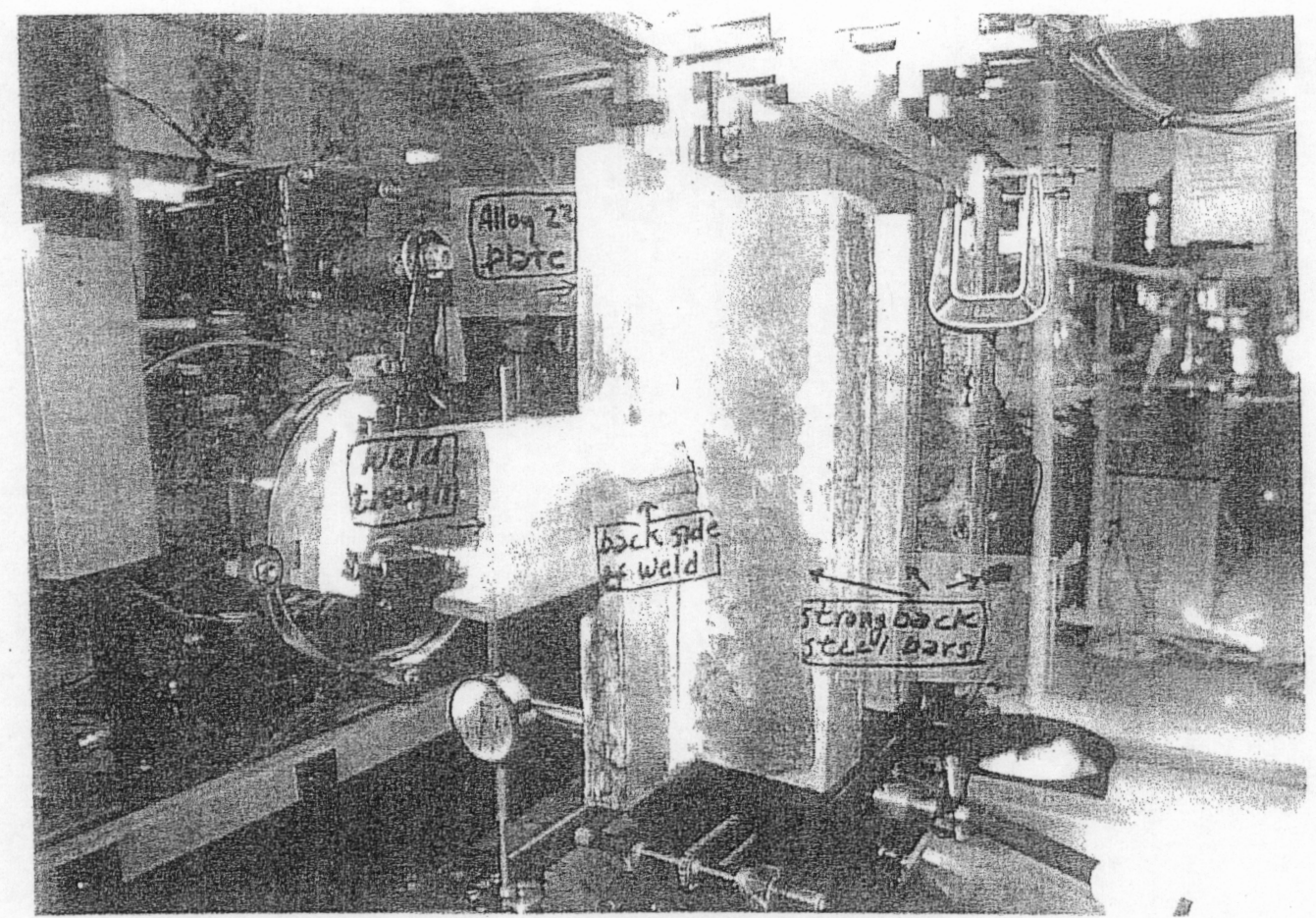

Figure 7. Rear view of the Weld Plate in the laser peening fixture.

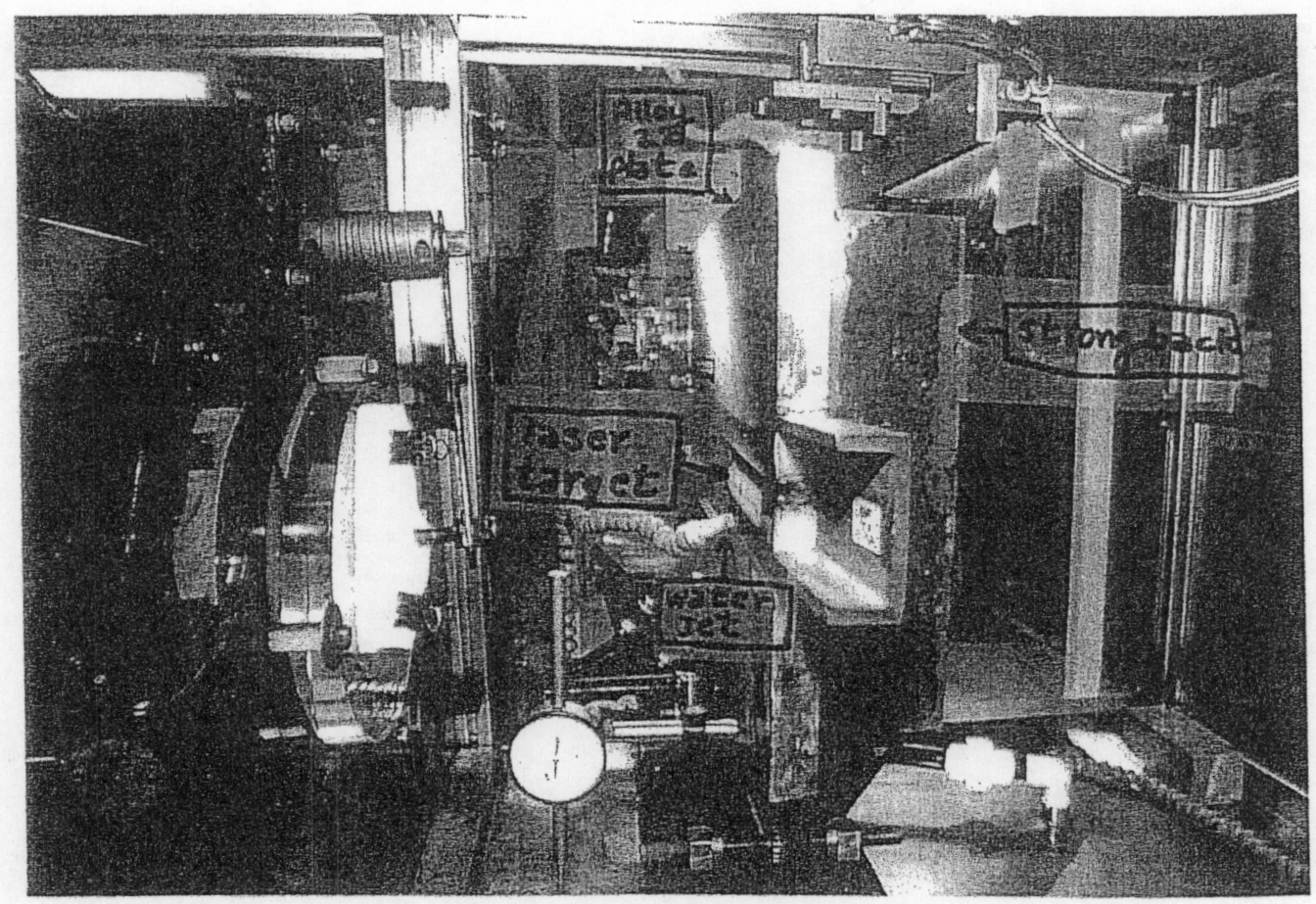

Figure 8. Front view of the Weld Plate being laser peened. 


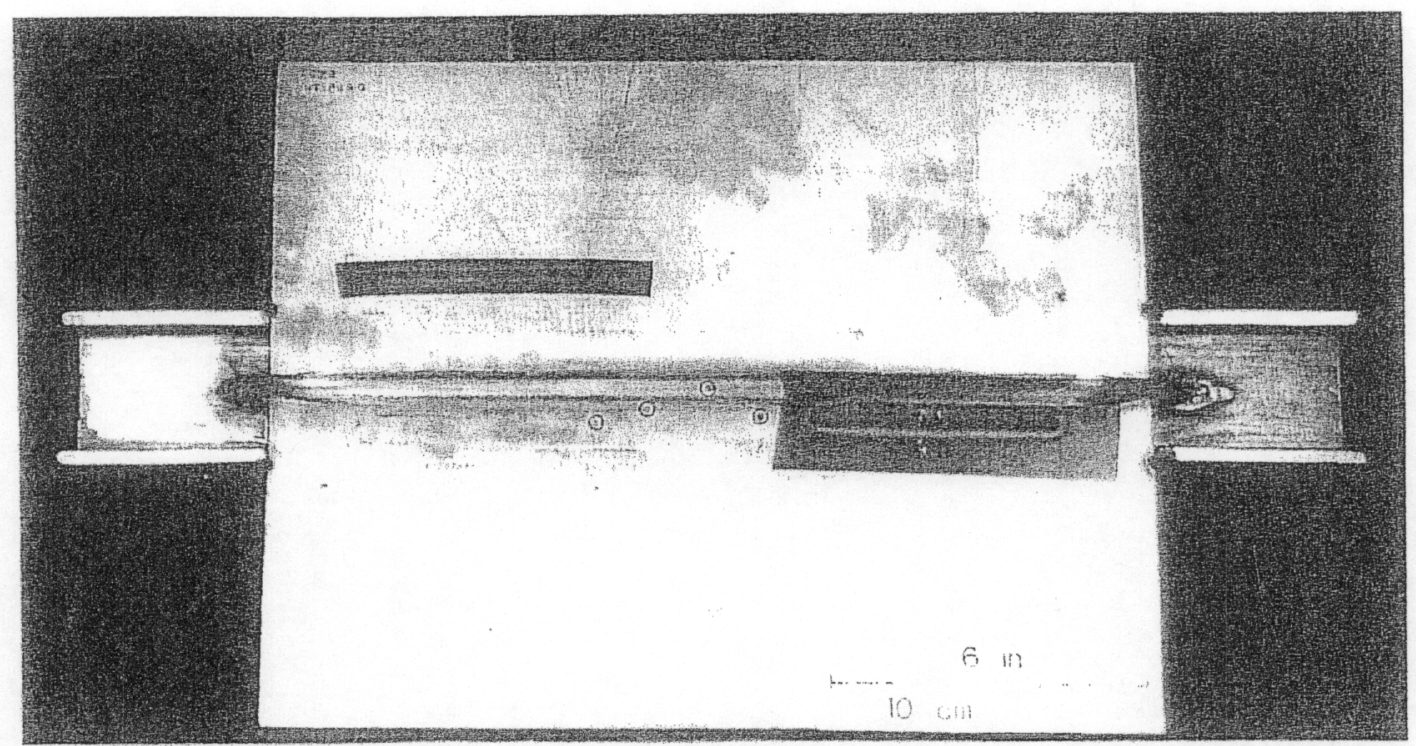

Figure 9. Weld Plate after laser peening. The end protrusions are welding troughs. The four ring cores near the middle were employed for stress measurements made before laser peening. The two strips of laser-absorbing black electrician's tape reveal the laser shot patterns and depressions caused by shock wave plastic deformation. Note the stillsmooth surfaces of the HAZ near the fusion boundary. This likely resulted from hardening by precipitation and ordering, but this seemed not to diminish the effectiveness of the laser peening.

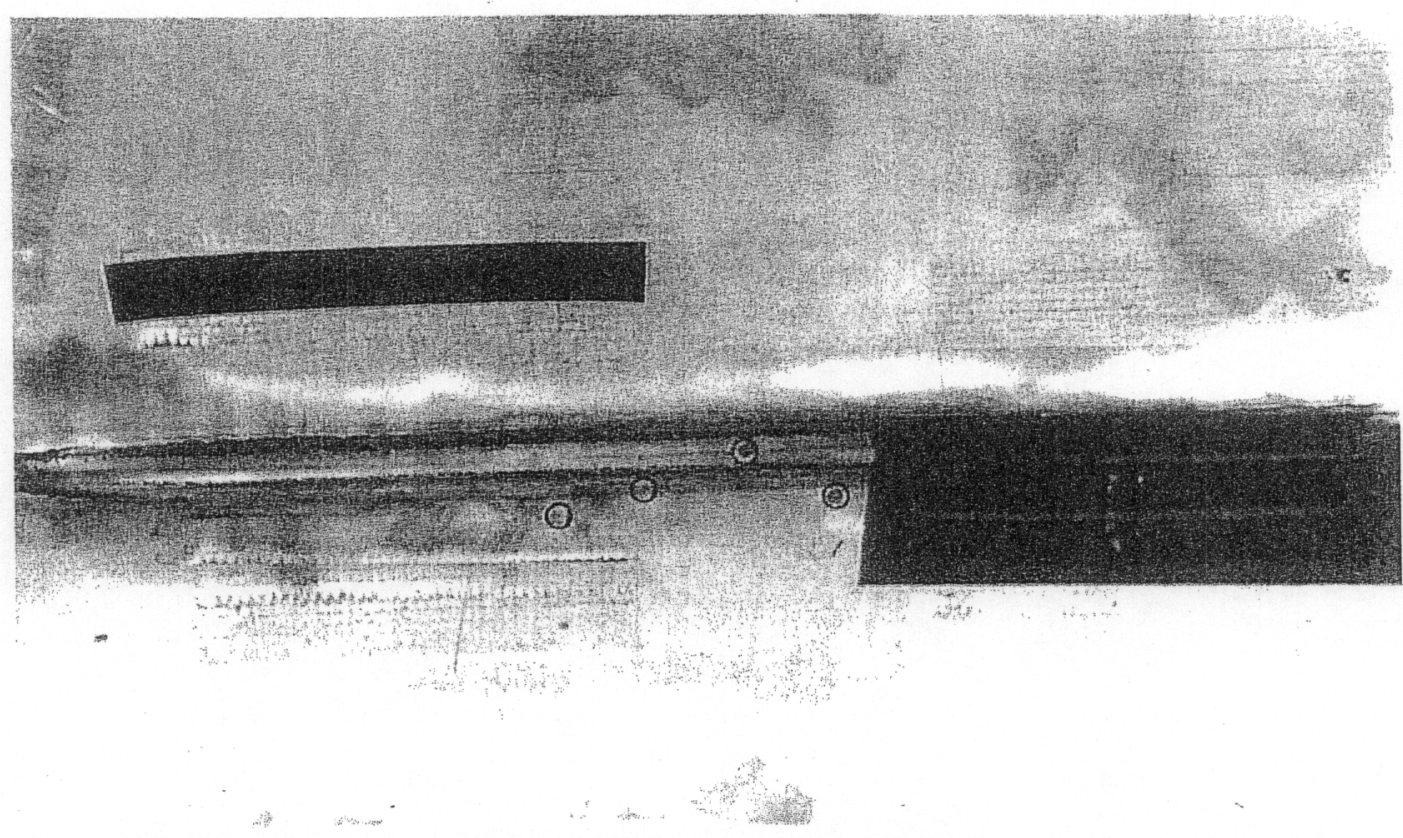

Figure 10. Higher magnification view of Figure 9 with better-defined peening depressions and other features. 


\section{RESULTS AND DISCUSSION}

\section{Laser Peening of As-Received Plate}

The residual stresses of the As-Received Plate are plotted in Fig. 11. Three stresses, STRESS1, STRESS2, and STRESS3, represent the three rosette directions at $0^{\circ}, 45^{\circ}$, and $90^{\circ}$. STRESS1 is the reference direction at $0^{\circ}$. STRESS2 and STRESS 3 are in the counterclockwise directions of $45^{\circ}$ and $90^{\circ}$, respectively. All three stresses lie in a plane parallel to the surface. The negative stresses are compressive and the positive, tensile. The MINIMUM and MAXIMUM stresses and PHI are calculated using Mohr's Circle for stress.
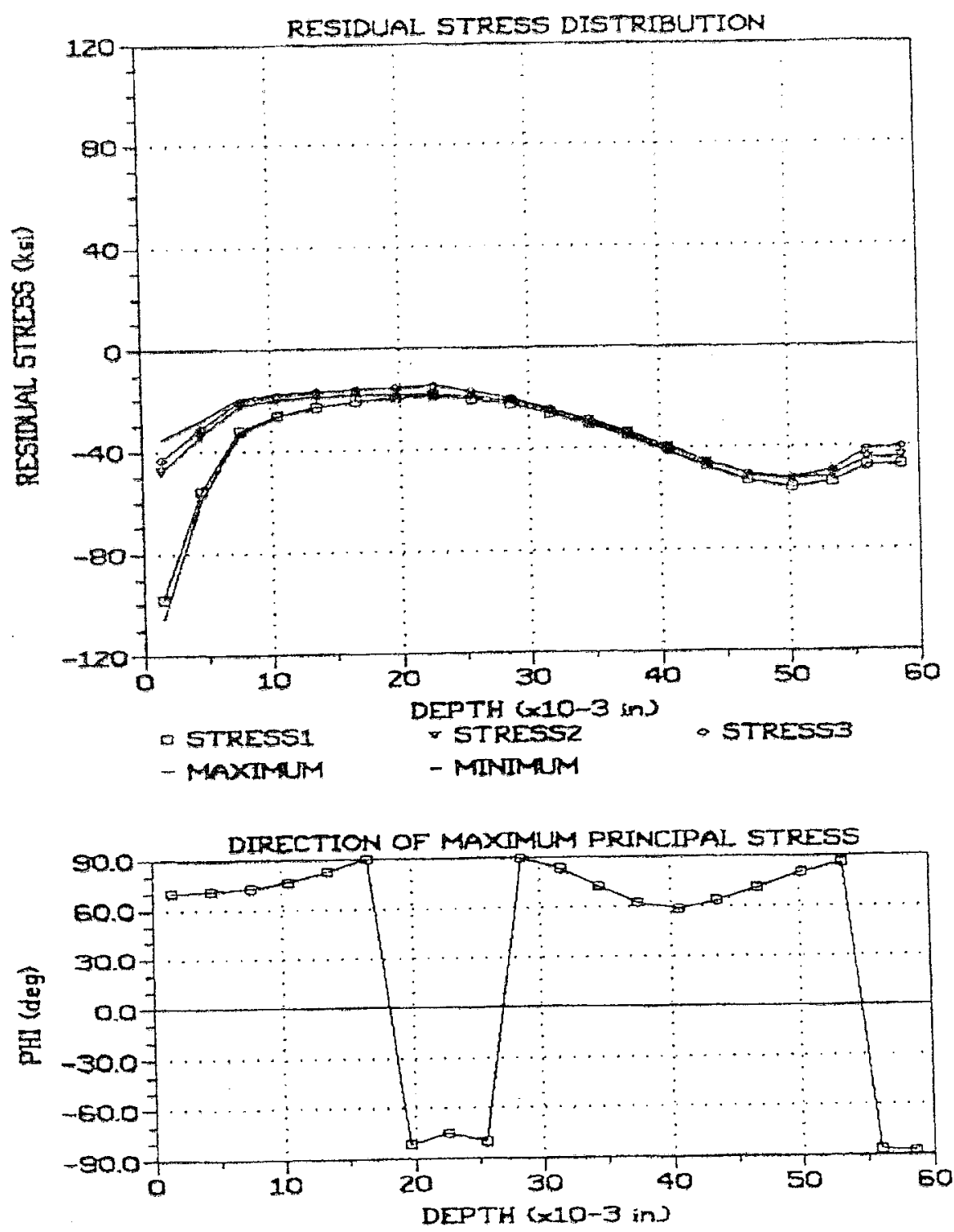

Figure 11. Residual stresses in As-Received Plate. The stress measurement was made on a lapped, electropolished surface of the plate. The compressive stresses are introduced during plate production and measure 35-105 ksi in the near-surface material. 
In analyzing stresses from the viewpoint of SCC, the more tension that exists, the worse the stress, and the more compression there is, the better because it counteracts SCC. Also, nearer the surface of the material is more critical because that is where the corrodent resides. In addition, since tensile stresses might be introduced accidentally after laser peening by handling damage, relaxation, or other circumstances, the higher the residual compressive stresses, the better because they offset tensile stresses that might be inadvertently introduced later on. In keeping with this logic, the minimum and maximum (extreme) stresses in the near-surface material are employed to represent the stresses germane to SCC. In Fig. 11, the near-surface residual stresses are 35-105 ksi, compressive, a tremendous buffer against SCC.

Discussions about the production process for Alloy 22 plate with John Grubb of Allegheny-Ludlum and with Raul Rebak of Haynes revealed that compressive stresses are introduced during plate production by water spray quenching after solution annealing and probably by grit or shot peening prior to acid pickling. The quenching is done to retain the alloying elements, $\mathrm{Cr}, \mathrm{Mo}$, and $\mathrm{W}$, in solid solution to maximize corrosion resistance. The mechanical shot peening is done to rid the surface of its tenacious thin oxides. Shot peening will also introduce compressive stresses on the surface. However, Haynes sometimes employs molten salt baths at $900^{\circ} \mathrm{F}\left(482^{\circ} \mathrm{F}\right)$ to clean the surface, which would not introduce stresses. Huntington Alloys has not yet been queried on this subject, but their processes are likely to include those mentioned above. A comprehensive description of the plate processing steps needs to be done for all Alloy 22 material produced for YMP. It might arise that any step that affects residual stress will have to be incorporated in the procurement specifications and/or that the residual stress in the plate will have to be stipulated along with the method of measurement.

\section{Laser Peening Parameters and Results}

Based in part on earlier work on the nickel alloy Inconel 718, eight different combinations of energy density and pulse durations were selected to determine which of these would be best for Alloy 22. These parameters are given in Table I as four tests using a single pass and four tests using a double pass. Testing was done on the lapped and electropolished As-Received Plate of Fig. 4. The eight test areas were spaced about 1" from each other along As-Received Plate to avoid overlap of their strain fields and 0.5 " or more from the ends to provide mass constraint against the strain fields.

Fig. 12 shows some of the laser peening test sites. Each site is $12 \mathrm{~mm}$ by $12 \mathrm{~mm}\left(0.5^{\prime \prime} \times\right.$ $\left.0.5^{\prime \prime}\right)$ and is comprised of a 4 by 4 array of laser shots, where each shot is $3 \mathrm{~mm}$ by $3 \mathrm{~mm}$. The $0.5^{\prime \prime} \times 0.5^{\prime \prime}$ area of the sites readily accommodated the $0.25^{\prime \prime}$ diam. ring core of the stress measurements, the results of which are given in Table I. The far right ranking column of Table I shows the 1-2-3 best parameters. These three parameters were analyzed with those from a larger database on Alloy 713, not shown here, to arrive at the best parameters; these are given in Table II.

A cursory amount of surface profilometry, hardness and microhardness testing, and AFM was done on the As-Received Plate before (seen in Fig. 4) and after (seen in Fig. 12) laser peening. 

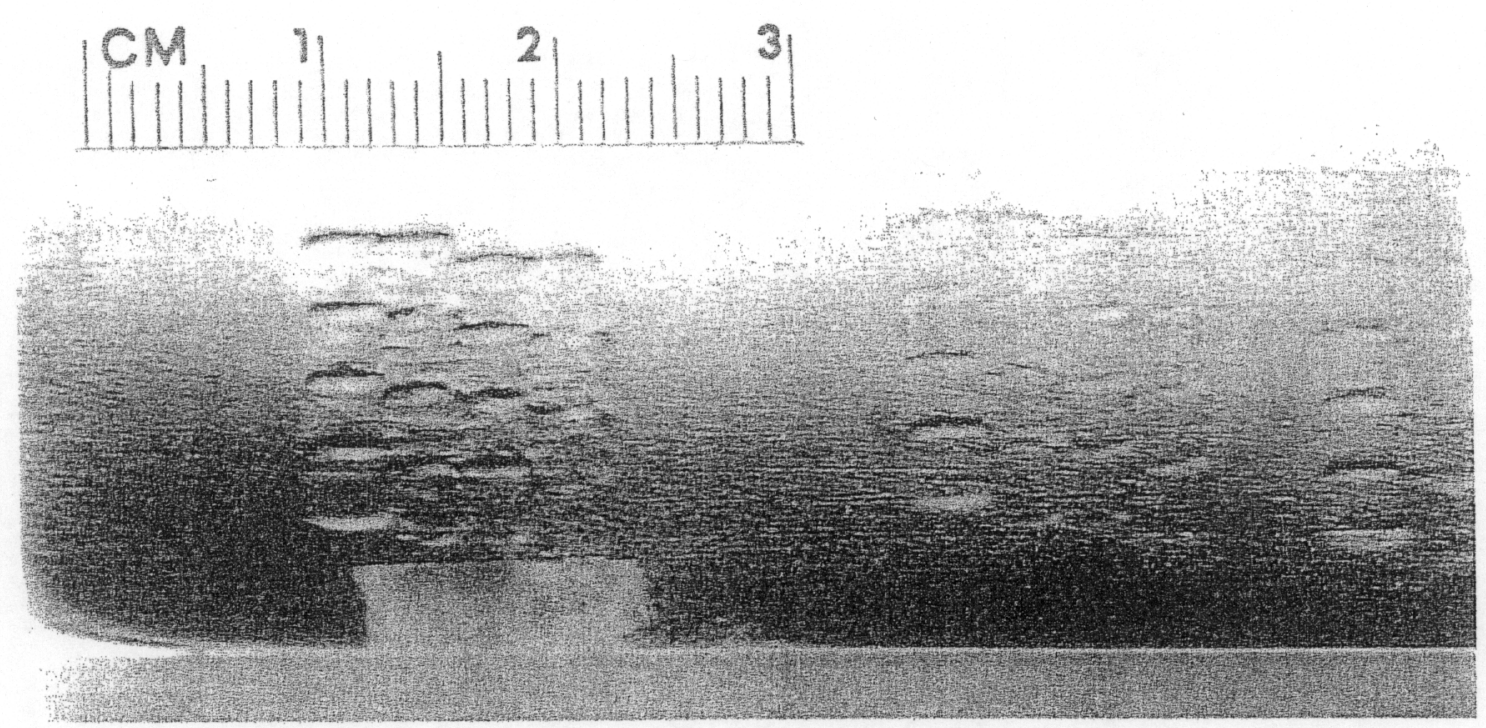

Figure 12. As-Received Plate with laser peening depressions. The plate was employed to determine the laser operating window for Alloy 22. Each site is 12 $\mathrm{mm} \times 12 \mathrm{~mm}$ and consists of a $4 \times 4$ array of $3 \mathrm{~mm} \times 3 \mathrm{~mm}$ laser shots.

Table 1-Test parameters and their resulting residual stresses for determining the laser operation window for Alloy 22.

\begin{tabular}{|c|c|c|c|c|c|c|c|c|c|}
\hline \multicolumn{7}{|c|}{ [-Test Parameters } & \multicolumn{3}{|c|}{ [-Stresses - $]$} \\
\hline \multirow[t]{2}{*}{$\begin{array}{l}\text { Site } \\
\text { no. }\end{array}$} & \multirow[t]{2}{*}{$\begin{array}{l}\text { Single } \\
\text { pass }\end{array}$} & \multirow[t]{2}{*}{$\begin{array}{l}\text { Double } \\
\text { pass }\end{array}$} & \multirow[t]{2}{*}{$\begin{array}{l}\text { Pulse } \\
\text { Duratio } \\
\text { n (ns) }\end{array}$} & \multirow{2}{*}{$\begin{array}{l}\text { Set } \\
\text { point } \\
\text { Energy } \\
\text { (J) }\end{array}$} & \multirow[t]{2}{*}{$\begin{array}{l}\text { Actual } \\
\text { energy } \\
\text { (J) }\end{array}$} & \multirow[t]{2}{*}{$\begin{array}{l}\text { Energy } \\
\text { density } \\
\left(\mathrm{J} / \mathrm{cm}^{2}\right)\end{array}$} & \multicolumn{2}{|c|}{$\begin{array}{l}\text { Range of } \\
\text { compressive } \\
\text { stresses (ksi) }\end{array}$} & \multirow[t]{2}{*}{$\begin{array}{l}\text { Rank } \\
1= \\
\text { best }\end{array}$} \\
\hline & & & & & & & $\begin{array}{l}\text { near } \\
\text { surface }\end{array}$ & $\begin{array}{l}\text { 1.5-mn } \\
\text { deep }\end{array}$ & \\
\hline \multicolumn{5}{|c|}{ As-Received Plate (from Fig. 11) } & & & $35-108$ & $40-50$ & \\
\hline 1 & $x$ & & 18.2 & 20 & 19.404 & 163.06 & \multicolumn{3}{|c|}{ Data lost during test } \\
\hline 2 & $x$ & & $18: 6$ & 18 & 17.892 & 150.35 & $92-100$ & $48-50$ & 4 \\
\hline 3 & $x$ & & 18.8 & 16 & 6.002 & 134.47 & $60-105$ & $55-70$ & 6 \\
\hline 4 & $x$ & & 19.4 & 14 & 14.112 & 118.59 & $39-75$ & $25-40$ & 7 \\
\hline 5 & & $x$ & $\begin{array}{l}19.2 \\
19.2\end{array}$ & $\begin{array}{l}14 \\
14\end{array}$ & $\begin{array}{l}14.238 \\
14.364\end{array}$ & $\begin{array}{l}119.65 \\
120.71\end{array}$ & $72-120$ & $72-85$ & 5 \\
\hline 6 & & $x$ & $\begin{array}{l}18.8 \\
19\end{array}$ & $\begin{array}{l}16 \\
16\end{array}$ & $\begin{array}{l}16.002 \\
16.002\end{array}$ & $\begin{array}{l}134.47 \\
134.47\end{array}$ & $90-115$ & $50-62$ & 2 \\
\hline 7 & & $x$ & $\begin{array}{l}20 \\
20\end{array}$ & $\begin{array}{l}18 \\
18\end{array}$ & $\begin{array}{l}18.774 \\
18.774\end{array}$ & $\begin{array}{l}157.76 \\
157.76\end{array}$ & $88-122$ & $78-82$ & 1 \\
\hline 8 & & $x$ & $\begin{array}{l}20 \\
20\end{array}$ & $\begin{array}{l}20 \\
20\end{array}$ & $\begin{array}{l}20.664 \\
20.916\end{array}$ & $\begin{array}{l}173.65 \\
175.76\end{array}$ & $92-110$ & 3246 & 3 \\
\hline
\end{tabular}


Table II-Testing laser peening operation parameters on Welded Plate.

$$
\mathrm{LP}=\text { laser peening }
$$

\begin{tabular}{l|lll}
\hline Passes on welded plate & $\begin{array}{l}\text { Name of LP } \\
\text { Parameters }\end{array}$ & \multicolumn{2}{c}{ LP Parameters } \\
\hline Left side (Area 1*) & LP-C & Energy density J/ $\mathrm{cm}^{2}$ ) & Pulse duration (ns) \\
$\quad$ First pass & & 164 & 20 \\
Second pass & 164 & 20 \\
& & & \\
Right side (Area 2*) & LP-D & & 20 \\
First pass & & 164 & 16 \\
$\quad$ Second pass & & 170 & \\
\hline
\end{tabular}

*Designations in Lambda Research's report to LLNL, 7/20/99.

\section{Surface profilometry}

Surface profilometry revealed that the laser peening depressions in the As-Received Plate were 6-8 $\mu \mathrm{m}$ deep and steep-sided compared to submicrometer undulations in the nonpeened regions around them. This is consistent with the well-known fact that the compression wave of laser peening introduces plastic deformation. Micron depth of depressions have been routinely observed in laser peening studies at LLNL on a variety of metals.

\section{Atomic Force Microscopy (AFM)}

Micrographs were taken of the bottom surface of the laser peening depressions of site 7 which, as per Table I, has a very high residual compressive stress of 88-102 ksi. Fig. 13 exhibits striations indicative of dislocation slip bands and, perhaps, deformation twins. These are seen at much higher magnification and superior resolution in the AFM micrograph of Fig. 14 where the vertical displacement of the striation indicated by the double red triangles is about $15 \mathrm{~nm}$, or about 50 atomic lattices. More analysis is required to better discern the striations as slip bands or twins. From a corrosion viewpoint, twins would be preferred because the residual strain energy from their formation is much less than for slip bands, and general corrosion increases markedly with increased strain energy. It has been shown that shock-loading can produce a high density of mechanical (deformation) twins in fcc Fe-32 $\mathrm{Ni}^{6}$, and Alloy 22 is also a high-Ni fcc alloy so it, too, may be favored for deformation twinning. There may be grain-tograin differences in the density of twins as suggested by the observation that the relative amount of twinning depends on the orientation of twin boundaries with respect to the direction of shock loading in fcc metals. ${ }^{7}$ Furthermore, orientations favoring twinning in

\footnotetext{
${ }^{6}$ W.C. Leslie, D.W. Stevens, and M. Cohen, "Deformation and Transformation Structure in ShockLoaded Iron-Base Alloys," p. 429 in High Strength Materials, V.F. Zackay, ed. (John Wiley Publisher, New York, NY, 1965) p. 382.

${ }^{7}$ G.E. Dieter, "Metallurgical effects of high-intensity shock waves in metals", in Response of Metals to High Velocity Deformation, P.G. Shewmon and V.F. Zackay, eds., Interscience Publishers, NY, 1961.
} 
$\mathrm{Ni}$ can produce hardening equivalent to a $90 \%$ reduction by cold rolling with only a $5 \%$ reduction by shock loading. ${ }^{8}$ Such hardening may have contributed to the nondeformed HAZ observed in Figs. 9 and 10 for the laser peened Weld Plate.
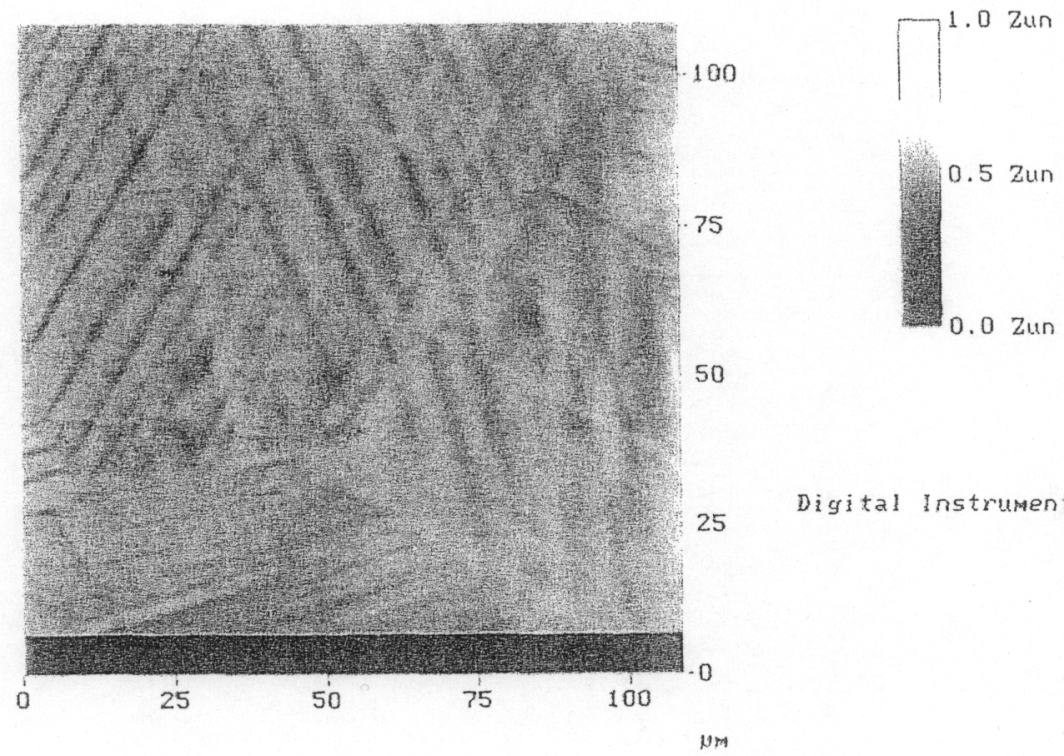

Digital Instruments NanoScope

Figure 13. Light micrograph of the striated bottom of a laser peening depression. Light micrograph taken with an AFM. Striations are indicative of dislocation slip bands and, perhaps, deformation twins.

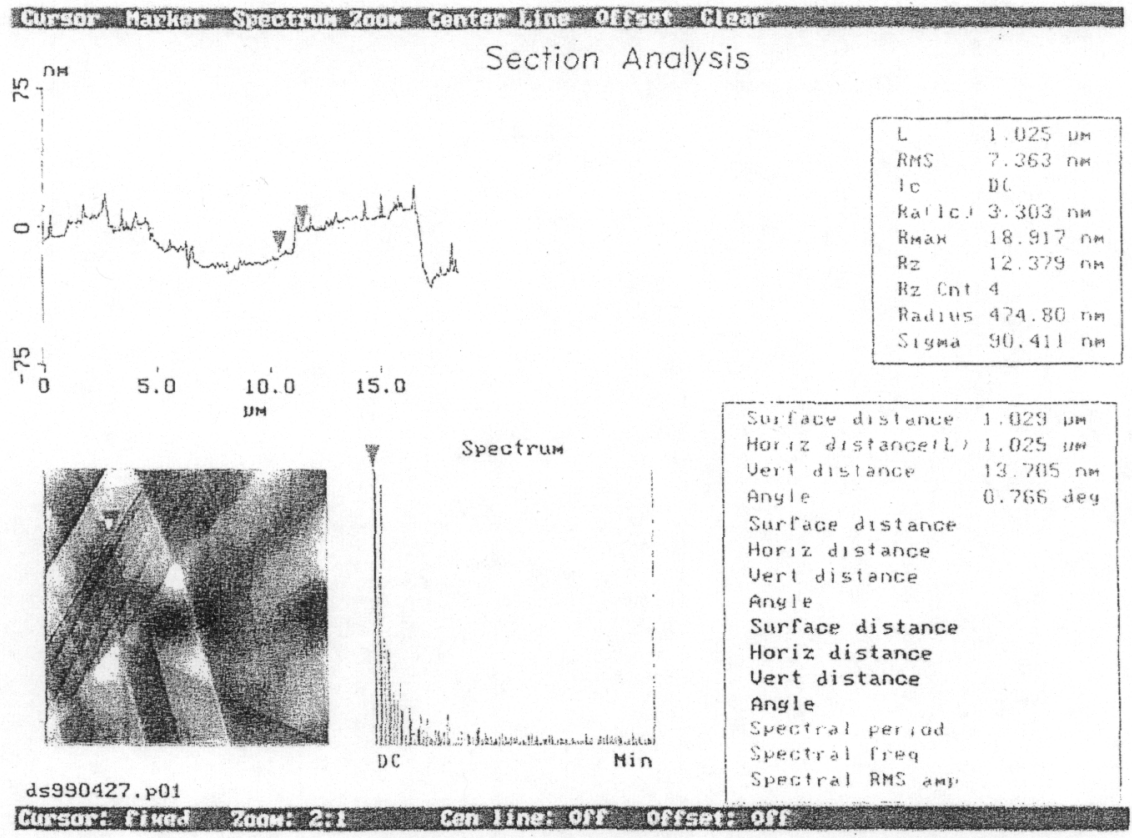

Figure 14. AFM micrograph of the striated bottom of a laser peening depression. The striation bounded by the double red arrows has a $15-\mathrm{nm}$ vertical displacement.

${ }^{8}$ C.S. Smith and C.M. Fowler, "Further metallographic studies on metals after explosive shock," p. 309 in Response of Metals to High Velocity Deformation, Interscience Publishers, NY, 1961. 


\section{Hardness and microhardness}

The laser-peened sites tested here were those having the larger residual stresses reported in Table $1, \# 7$ for micro-hardness and \#8 for hardness. Adjacent, non-peened metal was also tested. Rockwell B hardness tests (10 kg major load, 1/16" ball indenter) and DPH (diamond pyramid hardness) micro-hardness tests at 50, 100, and $200 \mathrm{~g}$ loads were done. Test block calibrations were done before testing. Two indents were made for each Rockwell B test and five for each DPH micro-hardness test. Variations and standard deviations were small within given tests. Their reduced data are given in Table III, along with corresponding residual compressive stresses.

From the last column on the right of Table III it is seen that:

- The increase in DPH micro-hardness averages 8\% (from 10, 8,7\%).

- The increase in Rockwell hardness is $2 \%$.

- The increase in residual Stress is $150 \%$, which is about $20 X$ greater than for DPH micro-hardness and 75X greater than for Rockwell hardness.

Table III-Hardness, microhardness, and residual compressive stress of AsReceived Plate before and after laser peening.

\begin{tabular}{|c|c|c|c|c|c|}
\hline \multirow[t]{2}{*}{ Property } & \multicolumn{2}{|c|}{ Before LP } & \multicolumn{2}{|c|}{ After LP } & \multirow{2}{*}{$\begin{array}{l}\% \text { Increase } \\
\text { from } L P\end{array}$} \\
\hline & Hardness & Depth $(\mu \mathrm{m})^{8}$ & Hardness & Depth $(\mu \mathrm{m})$ & \\
\hline DPH-50g & 230 & 2 & 253 & 3 & 10 \\
\hline DPH-100g & 255 & 5 & 288 & 5 & 8 \\
\hline DPH-200g & 231 & 15 & 262 & 12 & 7 \\
\hline Rockwell B & 93.65 & NA & 95.7 & NA & 2 \\
\hline \multirow{2}{*}{$\begin{array}{l}\text { Residual } \\
\text { compressive } \\
\text { stress }\end{array}$} & $\mathrm{ksi}$ & Depth $(\mu \mathrm{m})$ & ksi & Depth $(\mu \mathrm{m})$ & \\
\hline & $30^{*}$ & $>1500$ & $88^{* *}$ & $>1500$ & 150 \\
\hline
\end{tabular}

"Sampling depth of diamond indenter in the metal.

*Minimum stress from Fig. 11.

**Minimum stress from Table I, Site 7 .

Hence, the increase in residual stress from laser peening is very much larger (a factor of 20 to 75 ) than the corresponding increase in hardness/micro-hardness. This is puzzling because both properties, hardness/micro-hardness and residual stress, are strongly dependent on the extent of plastic deformation from the shock wave, so one might expect a much stronger correlation between the two. It is not known why there is not.

Taking the largest DPH micro-hardness depth of $15 \mu \mathrm{m}$ and comparing it with the 1500 $\mu \mathrm{m}$ depth of residual stress shows that the micro-hardness depth is only $1 \%$ as deep as the residual stress. This may be mildly informative but it has no obvious cause-andeffect link to the puzzle. 


\title{
The Effect of Laser Peening on Residual Weld Stresses
}

\author{
Laser peening of the Weld Plate
}

The LP-C and LP-D areas depicted in Fig. 6 were laser peened with the setup shown in Figs. 7 and 8. The resulting peening indent patterns are evident in Fig. 9 and more so in Fig. 10. Note that they disappear in the heat-affected zone (HAZ) adjacent to the weld. It is believed that this lack of plastic deformation resulted from hardening by precipitation and ordering reactions in the HAZ. Results reported below indicate that this hardening had no apparent effect on the peening-induced residual stresses.

\section{Residual stress measurements and analysis}

Residual stress measurements were made at four sites (center of fusion zone, HAZ adjacent to fusion boundary, HAZ 0.2" from fusion boundary, and HAZ $0.3^{\prime \prime}$ from fusion boundary) for each of the laser peening conditions:

before laser peening,

after laser peening with LP-C parameters, and

after laser peening with LP-D parameters)

for a total of twelve measurement sites. A map of these is shown in Fig. 15. The measurement sites were spaced about 1" apart to avoid overlap of their strain fields.

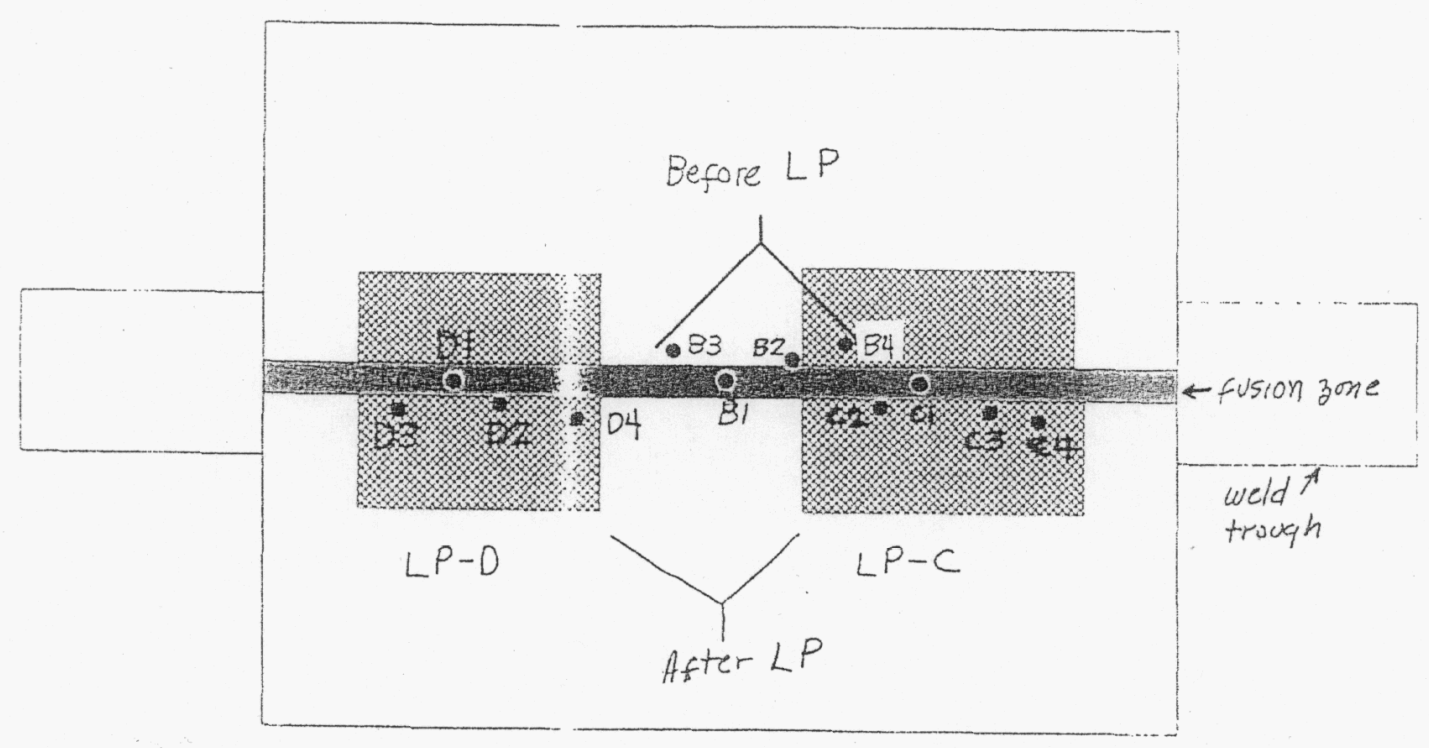

Figure 15. Map of stress measurement sites of Weld Plate before and after LP. The hatched areas have been laser peened. The "1" sites 9B1-D1) are at the center of the fusion zone and those "2"- 4 " are increasingly outward in the HAZ.

Residual stress distributions for all of the sites are plotted in Fig. 16. The four measurement sites (center of fusion line, etc.) comprise the horizontal axis of Fig. 16 and the three laser peening conditions (before laser peening, etc.) comprise the vertical axis. 
A qualitative inspection of Fig. 16 indicates that that both laser operating conditions, LP-

$C$ and LP-D, significantly transformed the residual tensile stresses into compressive stresses and that LP-Cdid so better.

Table IV was generated to analyze data extracted from the plots of Fig. 16, employing (as before) minimum-maximum stresses for the near-surface material. From D4 and D5 of Table IV and Fig. 16, it is seen that compressive stresses deep in the material drifted undesirably into the tensile region of the two outermost positions in the HAZ. This and the other evaluations given in Column E of Table IV solidify the result that LP-C parameters gave better stress relief than the LP-D parameters. Following are some other key results.

\section{Before laser peening}

- The stresses at the fusion line center are a mix of $30 \mathrm{ksi}$ compressive- $-42 \mathrm{ksi}$ tensile. In the HAZ, all stresses are about $30-80 \mathrm{ksi}$ tensile with an average of roughly $70 \mathrm{ksi}$. [from B1-B4 of Fig. 16 and Table IV]

- For material at all depths, the tensile stresses can reach $100 \mathrm{ksi}$ and frequently exceed the nominal yield value of $47 \mathrm{ksi}$ for this heat. This requires that work hardening occurred. [from Table IV, Cells $B(3-5)$ ]

\section{After laser peening}

- Laser peening with the superior LP-C parameters places the near-surface material under compression of $2-25 \mathrm{ksi}$ or better, thereby precluding the occurrence of SCC. [from Table IV, Cell C3]

Table IV - Residual stresses in Welded Plate beiore and after laser peening.

- Positive stresses $(+)$ are tensile, negative $(-)$ are compressive.

- Column E shows that that the laser parameters of LP-C are better than those of LP-D.

\begin{tabular}{|c|c|c|c|c|c|}
\hline & A & B & C & $\mathrm{D}$ & $\mathrm{E}$ \\
\hline & $\begin{array}{l}\text { Position relative to } \\
\text { the weld }\end{array}$ & Before LP & $\begin{array}{c}\text { After LP-C } \\
160 \mathrm{~J} / \mathrm{cm}^{2}, 20 \mathrm{~ns} \\
\text { plus } \\
160 \mathrm{~J} / \mathrm{cm}^{2}, 20 \mathrm{~ns}\end{array}$ & $\begin{array}{l}\frac{\text { After LP-D }}{160 \mathrm{~J} / \mathrm{cm}^{2}, 20 \mathrm{~ns}} \\
\text { plus } \\
170 \mathrm{~J} / \mathrm{cm}^{2}, 16 \mathrm{~ns}\end{array}$ & $\begin{array}{l}\text { Better: } \\
\text { C or D? }\end{array}$ \\
\hline 1 & Center of fusion zone & -20 to +45 & -35 to -95 & -50 to -58 & Neither (tie) \\
\hline 2 & $\begin{array}{l}\text { HAZ adjacent to } \\
\text { fusion boundary }\end{array}$ & +35 to +62 & -8 to -38 & -12 to -60 & D, slightly \\
\hline 3 & $\begin{array}{l}\text { HAZ } 0.2 \text { " from fusion } \\
\text { boundary }\end{array}$ & +35 to +81 & -2 to' -25 & $\begin{array}{c}-40 \text { to }+5 \text { but up } \\
\text { to }+40 \text { deeper } \\
\text { (bad) }\end{array}$ & $\begin{array}{c}\text { C, very } \\
\text { considerably }\end{array}$ \\
\hline 4 & $\begin{array}{l}\text { HAZ } 0.3^{\prime \prime} \text { from fusion } \\
\text { boundary }\end{array}$ & +30 to +81 & $\begin{array}{l}-5 \text { to }-30 \text { and } \\
\text { down to }-.55 \\
\text { deeper (good) }\end{array}$ & $\begin{array}{l}0 \text { to }-70 \text { but up } \\
\text { to }+25 \text { deeper } \\
\text { (bad) }\end{array}$ & $\begin{array}{c}\text { C, very } \\
\text { considerably }\end{array}$ \\
\hline
\end{tabular}



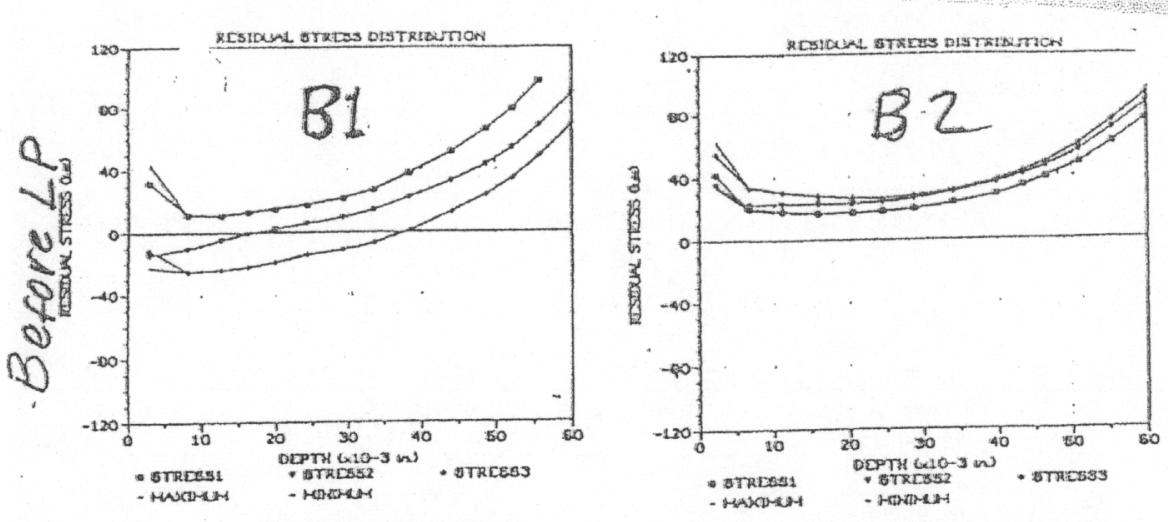

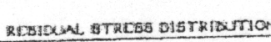
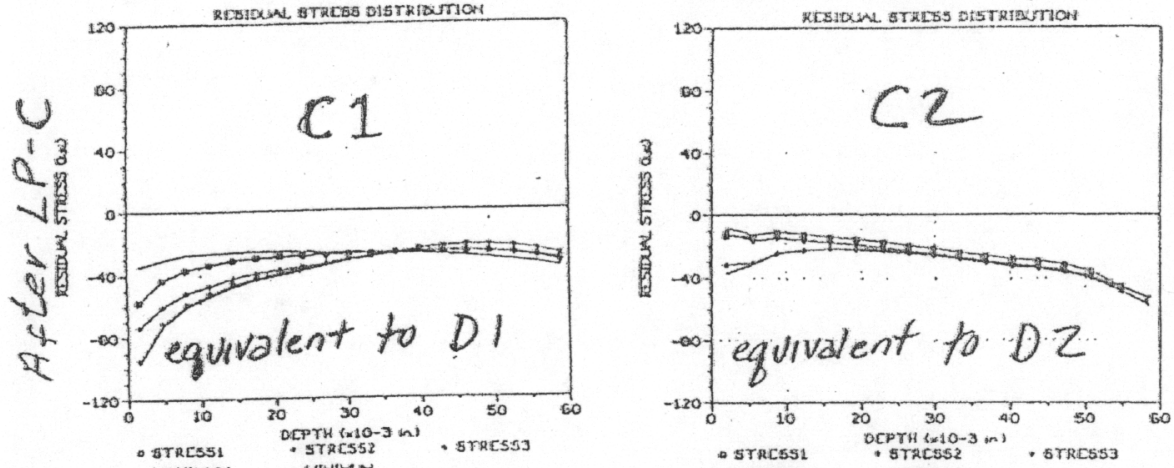

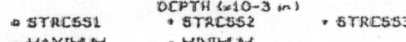

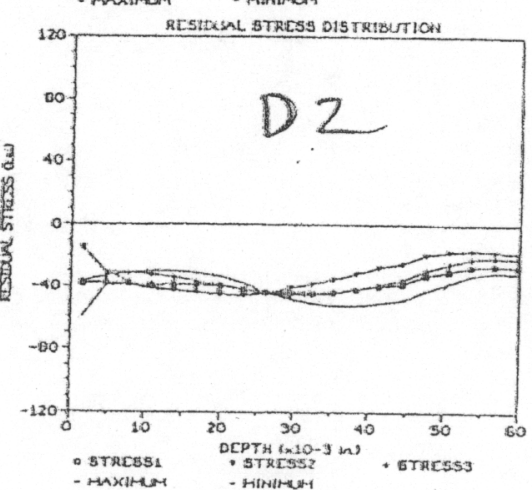

HAz adjacent to

center of fuston zone

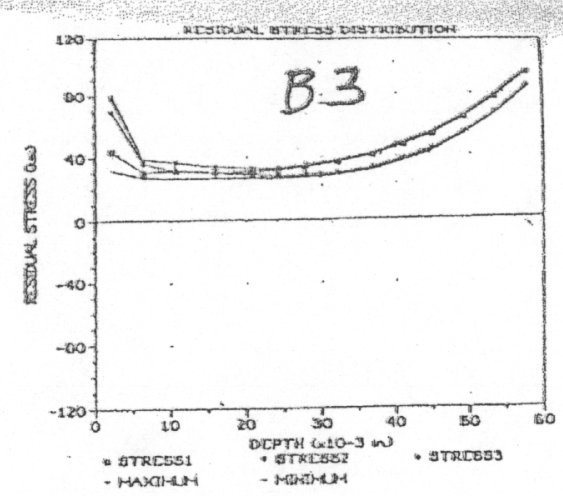

REBIOLWL STKLES DISTRIBUTIOA

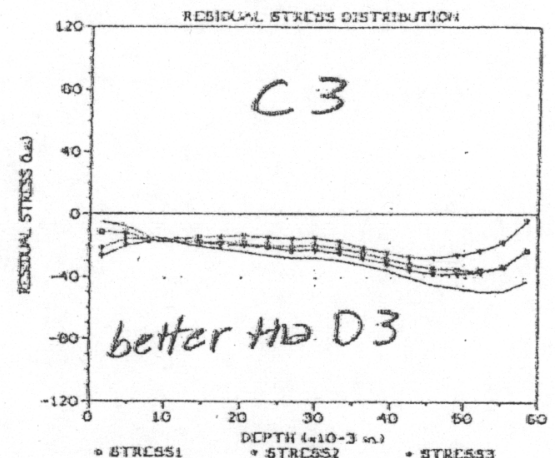

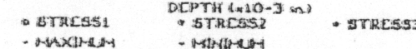

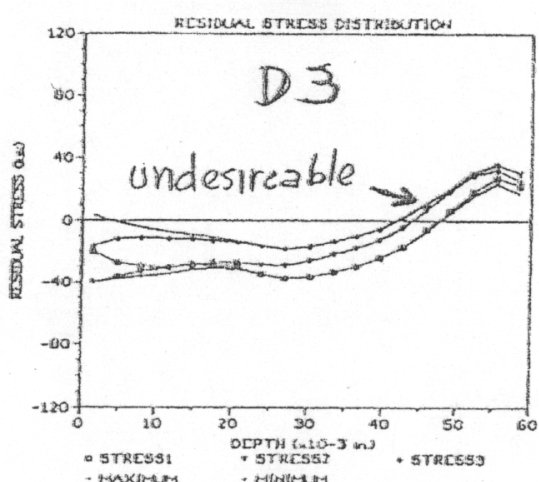

HAZ $0 . z^{\prime \prime}$ from fustorn boundary
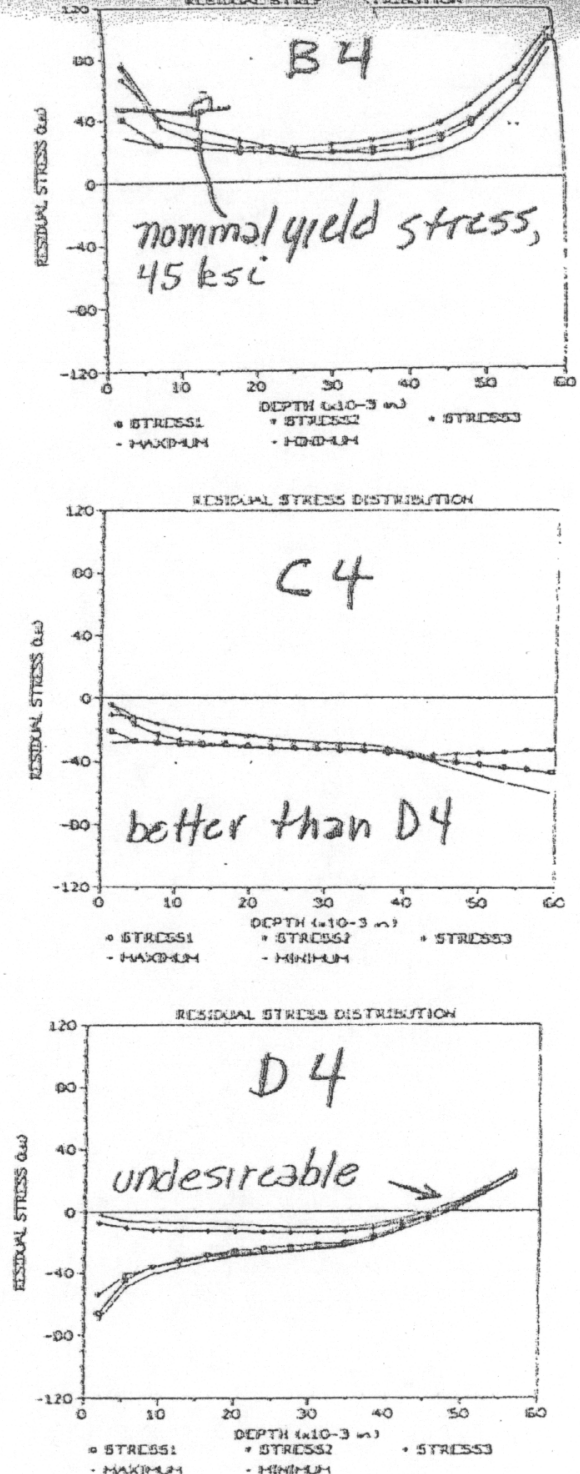

HAZ $0.3^{\prime \prime}$ from fos 100 bownd art

$$
\text { fusion boundary }
$$

Figure 16. Residual stress distributions in Weld Plate before and after laser peening. The four plots left to right start at the center of the fusion zon and proe plots top to bottom are the three laser peening (LP) conditions: Before LP, After LP-C, and After LP-D. Note the nominalyield stress for as-received Alloy 22 in B4. Inspection indicates that LP-C is better than LP-D. 


\section{RECOMMENDATIONS}

\section{Determine general corrosion rates of laser-peened weld metal}

Plastic deformation is known to increase the rate of general corrosion and laser peening introduces plastic deformation (cold working) as evidenced by the $6-8 \mu \mathrm{m}$ deep indents it forms. The plastic deformation zone may extend 1 or $2 \mathrm{~mm}$ into the metal. The effect of such deformation on corrosion should be determined by AFM measurements of general corrosion rates before and after laser peening.

Additional peening studies are required to optimize the laser operation parameters.

- Add a third pass at the $160 \mathrm{~J} / \mathrm{cm}^{2}-20 \mathrm{~ns}$ level. This proved advantageous for Ti$6 \mathrm{~A} 1-4 \mathrm{~V}$.

- Explore the $160-200 \mathrm{~J} / \mathrm{cm}^{2}$ regime for both double and triple passes at $20 \mathrm{~ns}$.

\section{Measure deeper stresses}

Residual stress measurements have been limited to depths of 60 mils ( $1.5 \mathrm{ram}$ ) by the ring-core method but interest extends to the entire cross-section, known also as throughthe-thickness. This might be done using through-thickness slicing with strain gages as well as the neutron diffraction method.

\section{Establish structure-property relationships}

Relationships between laser peening parameters, deformation, microstructure, and general corrosion must be understood if engineering development of the laser process is to proceed with any certainty and understanding. It is best to do surface and crosssection metallography, SEM, TEM, and XRD before and after welding and laser peening to reveal microstructural changes and plastic deformation effects and their likely effects on corrosion. The focus should be on phase instabilities such as TCP intermetallic precipitation and ordering. 


\section{CONCLUSIONS}

1. Prototypical fusion welding of Alloy 22 plate introduced residual stresses in the fusion zone and in the HAZ extending out at least $0.5^{\prime \prime}$ from the center of the weld. These stresses are tensile in the HAZ and a mix of compressive and tensile in the fusion zone.

2. Near-surface, SCC-sensitive, residuattensile stresses in the HAZ are 30-80 ksi tensile and remain highly tensile to a depthof $1.5 \mathrm{~mm}$, the measurement limit in this work. These are on the order of the nominal yield stress of $45 \mathrm{ksi}$ for Alloy 22 plate and thus may promote SCC.

3. Compressive forces driven into the weldment by laser peening replaces the nearsurface detrimental tensile stresses with compressive stresses of 2-25 ksi or better that would not support SCC. This stress conversion occurs in at least the top $1.5 \mathrm{~mm}$ of the metal without significant heating and appears to be a potential solution to the SCC problem.

4. Quenching and shot or grit peening during production of Alloy 22 plate imparts compressive stresses of 40-100 ksi that would thwart SCC. This means that if seamwelded hollow cylinders likewise gain compressive stresses upon post-weld annealing and quenching, and closure welds are laser peened, all of the surfaces of the canister will be under compression, thereby precluding SCC in the outer material of the Alloy 22 canister.

5. The compressive shock wave from laser peening imparts cold working in the form of depressions 6-8 $1 \mu \mathrm{m}$ deep.

6. Microscopy of the surface of the laser peening depressions shows striations typical of dislocation slip bands and deformation twins. The latter would impose less residual stress and thus, less accelerated general corrosion.

7. Laser peening of the as-received plate increases its residual compressive stresses by $140 \%$, much more (by a factor of 20 to 75 ) than it does for corresponding increases of $2-10 \%$ ha hardness/microhardness. This large difference is puzzling because both properties (residual stress, hardness) are strongly dependent on the plastic deformation introduced by the shock wave of laser peening and, therefore, a more equitable change would be expected.

8. Laser peening should be further characterized and engineered to help preclude SCC in Alloy 22 canisters. 


\section{ACKNOWLEDGEMENTS}

The authors wish to acknowledge the following contributors (in alphabetical order)for this effort.

- John Elmer for valuable advice and guidance on welding and welding metallurgy.

- Ed Fehring for profilometry measurements.

- John Halpin and Curt Neeb for their skillful operation of the laser.

- Brian Quintard and Joseph Martinez of LLNL-TID for their excellent digital photography of the samples and the laser peening set-up.

- Ed Sedillo of LLNL for cutting and lapping of samples, assisting in their electropolishing, and hardness and microhardness testing.

- Chris Steffani of LLNL for his systematic development and use of the optimum electropolishing parameters. 